\title{
Aleksander Nalaskowski*
}

Toruń

\section{Szkoły jednopłciowe - powrót do intymności kształcenia}

Swego czasu oglądałem w TV wywiad, a właściwie reportaż o Krzysztofie Zanussim. W jednej z sekwencji artysta udzielał odpowiedzi czy toczył monolog, mając w tle urządzenia gimnastyczne na poddaszu własnego domu. Był to bodaj jakiś niewielki ,atlas” do ćwiczeń siłowych, rower stacjonarny, etc. Zagadnięty o to reżyser żachnął się, stwierdzając, że ćwiczenia cielesne, które uprawia, są dlań kwestią bardzo intymną i nie chce być oglądany czy rejestrowany w trakcie ich wykonywania. Poci się bowiem, może nawet robi zabawne miny czy nie zawsze dość zgrabnie wykonuje ruchy.

$\mathrm{W}$ tej wypowiedzi Zanussi dotkną bardzo istotnej dla wychowania i obyczajowości kwestii, a mianowicie obszaru ludzkiego wstydu, intymności czy prywatności. To problematyka niemal zapomniana i w pedagogice już chyba zupełnie nieobecna. A jednak tradycyjnie ważna i wciąż stanowiąca bardzo silny regulator społecznych zachowań. Spróbujmy się temu przyglądnąć jako jednemu ze źródeł społecznych interakcji. Zarówno w ich trajektorii, jak i treści.

Zakres i meritum obszarów przez nas chronionych jako prywatne czy osobiste, a niekiedy właśnie intymne, ulega znaczącym zmianom. A w zasadzie zmianom jednokierunkowym, czyli stałemu ograniczaniu. Pola osobiście niejawne bardzo się kurczą i z powierzchni sporego kontynentu redukują się do rozmiarów maleńkich wysepek. Erozja ta ma charakter aktywny. Nie polega bowiem na zaprzestaniu ochrony przestrzeni prywatnej, lecz nade wszystko na zamianie jej na przestrzeń publiczną, na afirmację czy wręcz

* Prof. zw. dr hab. Aleksander Nalaskowski pracuje na Wydziale Nauk Pedagogicznych Uniwersytetu Mikołaja Kopernika w Toruniu. 
wynoszenie na plakat tego, co niegdyś miało pozostawać sekretne. Czyli jakieś sprawy nie tylko przestały być chronione, lecz zostały wystawione w sklepowe witryny. Różnica jest zasadnicza. Jak między stratą zainteresowania niewiastą a wystawieniem jej jako towar na sprzedaż.

Te kroki są drobne i mało dostrzegalne. Ale widoczne i skuteczne. Spróbuję za pomocą przykładów pokazać ich zasadnicze reprezentacje.

Powszechnie wyrażamy zgodę na podsłuchiwane i śledzenie naszej korespondencji, w której przekazujemy najróżniejsze detale własnego życia. Nienaruszalność zaklejonej koperty przestała obowiązywać. Otwarcie na łącza internetowe czy komórkowe w różnych postaciach jest de facto cicho wyrażoną zgodą na monitoring spraw prywatnych. Wystarczy niewielka orientacja w charakterze technologii informacyjnych, aby uświadomić sobie, że tak naprawdę obszernie wysyłamy w świat wiadomości nie w zamkniętej i opieczętowanej kopercie, lecz na powszechnie dostępnych widokówkach. Adresaci ich to grupa poza naszą kontrola. Prawie zawsze dowiadujemy się, czy treść trafiła do miejsca przeznaczenia, a niemal nigdy do kogo jeszcze. I to jest nasz świadomy wybór i osobiste ryzyko. Codziennie wkalkulowujemy je w życie.

Znacząco zwiększyła się liczba osób i instytucji mogących od nas zażądać okazania dokumentu tożsamości czy ujawnienia numeru PESEL, który faktycznie jest furtką do wielu informacji o nas. Reguła ta obowiazzuje przy wielu umowach handlowych, porozumieniach czy w nawet prozaicznych sprawach życiowych.

Akceptujemy powszechny monitoring (czyli filmowanie) miejsc mniej lub bardziej publicznych bez jakiejkolwiek wiedzy, co się z nagraniami dzieje, jakie są procedury ich kasowania czy przechowywania. Na dobrą sprawę nas to nawet nie interesuje.

Zupełnie ignorujemy fakt, że nowoczesna technologia pozwala na zapis filmów małym i niewidocznym sprzętem optycznym wbudowanym w telefon komórkowy czy nawet imitację biżuterii. W wielu sklepach z elektroniką można niedrogo zakupić zestaw szpiegowski (podsłuch, kamerka) do niedawna dostępny tylko służbom specjalnym.

Tak naprawdę żyjemy w domach bez ścian i niemal bez wpływu na to, co ma stanowić nasz życiowy czy osobisty sekret. W jednym momencie wiele szczegółów naszego życia może stać się jawnych, powszechnie dostępnych i komentowanych. I tylko od woli kogoś innego zależy, czy wskazane wyżej możliwości zostaną wykorzystane czy nie. Pomijając etyczny wymiar tego zjawiska, trzeba sobie uzmysłowić, że w ten sposób tworzy się pewna otulina, stały wpływ na nasze środowisko psychologiczne. Żyjemy z tym jak z łuszczycą czy własnym łysieniem. Oczywiście, nam się to nie podoba, nie ma w nas akceptacji, ale dominuje postawa „a co ja mogę zrobić?”. Prawda 
jest, że na buncie możemy poprzestać. A tak zwana „ochrona danych osobowych" jako zapis prawny nie uchroniła nas przed bazami danych, gdzie koncerny handlowe i korporacje przechowują nasze personalia, dając znać o sobie między innymi poprzez telefony $z$ ofertami.

Wskazane wyżej przykłady wspierają w wielu obszarach hasła transparentności życia, „przełamywania tabu” i „,dzielenia się sobą”. Dlatego już nas zupełnie nie dziwią, chociaż nie wzbudzają aplauzu, wszelkie intymne wyznania osób publicznych, dyskusje o najsekretniejszych wymiarach życia, programy typu realisty show czy całe archipelagi portali oferujących voyeur, czyli podglądanie innych w najrozmaitszych sytuacjach. Niemal powszechną praktyką stały się rozbierane sesje popularnych dziennikarek, prezenterek pogody czy sportsmenek. A słynny coming out, czyli publiczne, a wręcz medialne przyznawanie się do homoseksualizmu weszło w salonowy rytuał.

Jeszcze raz powtarzam - wskazane fakty i praktyki nie bulwersują mnie, nie są przyczynkiem do szukania globalnego spisku podglądaczy. Stwierdzam jedynie fakt, że społeczna psychika jest zbyt słaba, aby się przed nimi bronić. A to siłą rzeczy zmienia naszą obyczajowość. Jeszcze dwie dekady temu niemożliwa byłaby telewizyjna reklama środków farmakologicznych usuwających nieprzyjemne i mocno skrywane dolegliwości, takie jak hemoroidy, wzdęcia, zgaga, prostata, brak wzwodu. Dzisiaj są tak samo uprawnione jak reklama aut, obuwia czy turystyki.

Nauczanie i uczenie się jest nieco jak sport w opinii Zanussiego. To czynność, proces, działanie niezwykle osobiste, a niekiedy intymne. Uczenie się polega na pokonywaniu własnych niedostatków, nieumiejętności, a także słabości. To także obszar uprawnionych błędów. Ucząc się, można się potykać, mówić głupstwa, robić pomyłki. Sam proces uczenia się/nauczania bezlitośnie obnaża nasze predyspozycje i ich brak. Zespół klasowy szybko staje się zbiorem podzielonych świadków. Uczniów podzielonych na tych, którzy w lot łapią i na tych, którym nie idzie. Podzielonych na uzdolnienia (matematycy, humaniści, przyrodnicy, artyści) i tych bez wyraźnych predyspozycji dających choćby niewielki sukces szkolny.

Osiągnięcia szkolne, niepowodzenia, potknięcia, brak uzdolnień, ograniczenia i deficyty rozwojowe, niesprawności to kwestie należące do najintymniejszej sfery człowieka. Nawet sobie nie zdajemy sprawy ze spustoszenia, jakie w dziecku może wywołać kompromitacja przed klasa, a raczej jej ujawnienie i nagłośnienie. Powiedzenie „nie opowiadaj matole, co się dzieje w szkole" jest ważnym, chociaż już znaczeniowo przeinaczanym echem szkoły jako swoistej intymności, czynności ukrytej, ukazywanej rzadko.

Tradycje szkolne niosą wiele informacji o sekretności i osłanianiu procesów rozwojowych dzieci kurtyną, parawanem intymności, endemiczno- 
ścią miejsca. Mylnie interpretowane i wyśmiewane stają się dla dyletantów pedagogicznych symbolem starej, zatęchłej, autorytarnej tradycji.

Taka jest geneza i istota szkolnych mundurków. Unifikacja zewnętrzna chroniła sekret szkolny i klasowy. Nic i nigdzie nie powinno wychodzić poza żakiet uniformu szkolnego. Identyfikacja z mundurkiem była identyfikacja ze szkoła, a co za tym idzie z miejscem, w którym błędy, potknięcia i niepowodzenia są uprawnione i nikt nie może ich wyśmiewać. Mundurek szkolny wskazywał, że człowiek jest in statu nastendi, jest w okresie rozwojowym, jeszcze się tylko zapowiada, przemienia i z tego tytułu ma specjalny status.

Posiedzenia rad pedagogicznych są od zawsze objęte tajemnicą. A dlaczego? Przecież nie omawia się tam zagadnień z zakresu obrony kraju czy produkcji systemów informatycznych dla przemysłu strategicznego. Oczywiście idzie tu o prywatność i najlepiej rozumiana godność ucznia. Bez względu na jego osiagnięcia i postępy. I to nie element lewicowej ideologii oświatowej, lecz ewangelicznie rozumiana cnota.

Wraz ze zmianami obyczajowymi, mentalnymi i prawnymi, których etiologii nie jesteśmy w stanie obecnie zrozumieć (jeśli wyjąć teorie spisków czy koncepcję totalnej wolności będącej rzekomo potrzebą każdej jednostki) właśnie proces edukacji, czyli kształcenia i wychowania, uległ niemal skrajnej deintymizacji. Z procesu osobistego i niezwykle indywidualnego stał się niemal przezroczystym tunelem przebiegającym w samym środku życia społecznego.

Jednym z elementów upublicznienia tego procesu jest zbiorowe taksowanie kolejnych roczników za pomocą tak zwanych egzaminów zewnętrznych. To nic innego jak pozbycie się pewnego marginesu interpretacji wyników współpracy dziecka i szkoły. Tradycyjna ocena od 2 do 5 czy od 1 do 6 informowała nie tyle o kompetencjach ucznia, ile o jakości jego współpracy z wykonawcami zadań edukacyjnych. Można było dodawać do niej ciche komentarze (,no tak, ale to mała szkoła na wsi” albo „ta placówka zawsze kształciła dobrych polonistów”). Obecna unifikacja egzaminacyjna wyraźnie i bezlitośnie, a przede wszystkim skutecznie stratyfikuje uczniów, porządkuje ich, zamykając w zbiorach ,głupich” i „mądrych”, podając to za pomoca certyfikatów do publicznej wiadomości. O ile onegdaj było: „mam czwórkę $\mathrm{z}$ chemii w tej szkole, u tego nauczyciela", to obecnie ten komunikat brzmi „średnio moi rówieśnicy zdali w Polsce chemię na $61 \%$, a ja na 54\% - jestem od nich słabszy". Siła rażenia takiego komunikatu jest znacząca, jak publiczne odarcie człowieka z ubrania. Reakcją nie zawsze jest wstyd i poczucie poniżenia, lecz przyzwyczajenie do własnego obnażenia, a w końcu jego akceptacja jako społecznej normy.

Szczególnym przejawem stopniowej likwidacji objętych restrykcją tradycji barier jest koedukacyjność życia społecznego. Od samego początku 
jest to nurt myślowy i działaniowy wpisany w rozmaite wcielenia ideologii lewicowych.

O ile na przełomie XIX i XX wieku kobiety walczyły o prawo przebywania w przestrzeni publicznej bez nakrycia głowy, to obecnie bez siania zgorszenia mogą się zupełnie obnażać na plażach. Zjawisko to przechodzi również na ledwie lekko skryte miejskie skwery, parki czy podmiejskie lasy. Idzie tu głównie o styl topless będący kobiecą odpowiedzią na męskie obnażone torsy. Hasło „wszyscy są równi” ma tu wyraźne konotacje. Gdzieś między owym nakryciem głowy a publicznym obnażaniem piersi zaistniała koedukacyjna szkoła.

Dotykamy zatem kwestii intymności płci. Ludzka cielesność, a szczególnie płciowość, to obszar szczególny. Był też zawsze szczególnie chroniony. Wyznaczano tu dość czytelne granice. W starożytności tak długo mężczyzna nie był nagi, jak długo napletek okrywał jego członka. Do dzisiaj dekolt nie jest golizną póki nie odkrywa sutków niewiasty. To tylko symbole granic. Innymi są odrębne toalety, kolorystyka stroju, pewne pozostałości obyczaju (np.: język kobiety - język mężczyzny, różnica między pijaną kobietą a pijanym mężczyzną, etc.).

Ale i w tej sferze dochodzi do istotnych, a rzec by można rewolucyjnych zmian. Przy czym pojęcia ,rewolucyjność” w żadnym obszarze życia nie wartościuję. To gwałtowna, spontaniczna i niekontrolowana zmiana zachodząca w obrębie danego społeczeństwa.

Otóż płeć stała się tematem społecznego dyskursu i sporów. Została, bodaj raz na zawsze, wyjęta ze sfery intymności do przestrzeni publicznej, uznano ją jako możliwą do wyboru, zmiany (fizycznej, mentalnej) i jest jednym z dominujących problemów współczesnej pedagogiki. Ludzka płciowość bywa wykorzystywana w reklamie, biznesie, działalności politycznej i w walce. Nic tak nie niszczy człowieka publicznego jak medialne oskarżenie o molestowanie seksualne czy pedofilię. Paradoksalnie oskarżenie o homoseksualizm jest zupełnie niegroźne, a posiadanie licznych partnerek czy partnerów jest wręcz chwalebne. Tak zwany coming out, czyli ujawnienie własnego homoseksualizmu stało się z czasem zbyt mało atrakcyjne. Pojawiły się więc zwierzenia „mój syn jest gejem”. Przy czym określenie „gej” jest eufemizmem dla nieco medycznego terminu „homoseksualizm”.

Płciowość stała się przedmiotem kłótni. Wypełzła na ulice w postaci parad homoseksualnych czy „marszu szmat”. Jednocześnie prowokując manifestacje rodzin hetero i agresję siłowych ugrupowań przypisywanych prawicy politycznej.

Dominujące nurty nie obejmują jednak nigdy całości społecznej zbiorowości. Rodzą się w nich opcje niszowe próbujące trafić do wybranych uczestników życia społecznego. Często mają one wymiar i rangę symbolu, 
albo lepiej - lokomotywy ciagnącej cały pociag niezgody na zachodzące zmiany.

Takim działaniem jest powrót do idei szkół jednopłciowych (osobnych dla chłopców i dziewcząt). W nauce przyjęło się to nazywać edukacją zróżnicowana.

Powołanie takiej placówki to wierzchołek góry lodowej, trójkąta, wewnątrz którego znajdują się istotne intencje merytoryczne. Powrót do tego „co już było” może okazać się istotnym działaniem nowatorskim. Odtworzenie zaniechanych tendencji może być w celach i skutkach niezwykle płodne. Przyjmując odpowiednie proporcje porównania, wystarczy wspomnieć, jak wielkim odkryciem była u początku lat dziewięćdziesiątych ubiegłego wieku kuchnia polska, „polskie jadło” czy „,chłopska gastronomia”. Do łask wrócił smalec, pierogi i żur. A przecież żaden z tych specjałów nie był sam w sobie nowy. Ale jako pewna tendencja była to reakcja na pojawiające się gęsto restauracje chińskie, hinduskie czy włoskie.

Edukacja zróżnicowana jest także reakcją na kulturową deintymizację życia, opisaną na wstępie tego tekstu. Jest więc przede wszystkim powrotem do hołubienia ludzkiej intymności będąc jednocześnie obliczem szerokiej a ukrytej propozycji zmian polegających na powrocie do uznanych za przebrzmiałe tradycji i doświadczeń.

A. Przede wszystkim wbrew dominującym nurtom kulturowym propagowanym przez „europejskich” psychologów, socjologów, a nade wszystko pedagogów różnica płci, jest tu rozumiana jako dana na zawsze (od narodzin do śmierci). I nie ulega żadnej z mieszczących się w rozumieniu natury zmian.

B. Generuje to nasamprzód najprostsze atrybuty zróżnicowania: strój, mimikę, gest, sposób poruszania się, używany język.

C. Likwiduje zjawisko cenzury. Gdy chłopcy cenzurują zachowania dziewcząt i na odwrót. To także wyrugowanie rywalizacji klasowej poza kryterium płci. Zmagają się uczniowie, wszyscy w kasie i nie dochodzi do podziału na „mniej zdolne, ale pracowite” uczennice i na „genialnych, ale leniwych chłopców". Wykluczenie płciowego kontekstu jednoznacznie sprowadza nauczanie i wychowanie na wyraźne tory skierowane do nie mniej jednoznacznego odbiorcy.

D. Edukacja zróżnicowana pozbawiona jest rywalizacji i działań koncyliacyjnych między grupami chłopców i dziewcząt. Skupia się na wyraźnie sprecyzowanym oddziaływaniu. Na każdą z tych płci innym.

E. Metodyka odrębnego nauczania chłopców i dziewcząt jest dość zasadniczo różna i nie petryfikuje poglądu, że „chłopcy to lotnicy, dziewczynki to kelnerki". Wykorzystuje się w niej dość istotne, znane i naukowo potwierdzone różnice w tempie, głębokości i adekwatności przyjmowanych 
informacji. To nie oznacza, że w którejkolwiek grupie osiagnięcia te są inne, a zwłaszcza lepsze. Tu przykład nieco techniczny. Produkcja elektrycznych gniazdek różni się od produkcji wtyczek. Ale by zaistniało zjawisko przepływu prądu, niezbędne są te dwa urządzenia, przygotowane w odmiennych technologiach i na osobnych maszynach. Razem dają jednak pożyteczną i skuteczną całość.

Nie jest przypadkiem, że szkoły dostarczające światowej populacji nowych generacji elit, niezbędnych rozwojowo, historycznie i strategiczne, są w większości szkołami jednopłciowymi. A to między innymi Eton, Harrow Hill, Rugby, szkoły Opus Dei. Moim zdaniem stworzenie systemu edukacji zróżnicowanej jako systemu powszechnego jest tylko kwestią czasu i wynikać będzie z czekającego nas powrotu do poszanowania ludzkiej intymności, prywatności i sensownie rozumianej indywidualności. Kwestią otwartą pozostaje, w którym pokoleniu się to stanie.

\section{Single-Gender Schools - Back to Intimacy of Education (Summary)}

The article indicates the value of varied education - for females and males separately, which tries to provide for differences in development of both sexes. The context for the afterthought is not the said differences but counter intimacy of life, i.e. decline of areas understood as private, intimate, personal, taboo. The author argues that developing man needs the said intimacy at the point of entering into the education path experiencing own failures. These are particularly painful if observed by the opposite sex representatives and simultaneously normal in terms of other course of development of representatives of both sexes.

Keywords: varied education; single gender schools; intimacy; counter intimacy of life.

\section{Szkoły jednopłciowe - powrót do intymności kształcenia (Streszczenie)}

Artykuł zwraca uwagę na wartość edukacji zróżnicowanej - prowadzonej oddzielnie dla chłopców i dla dziewcząt, która stara się uwzględniać różnice w rozwoju obojga płci. Kontekstem dla refleksji nie sąjednak owe różnice, ale deintymizacja życia, czyli zanik obszarów, rozumianych jako prywatne, intymne, osobiste, objęte tabu. Autor przekonuje, że dojrzewającemu człowiekowi potrzeba owej intymności właśnie wówczas, gdy wkracza na ścieżkę edukacji i przeżywa na niej swoje nie- 
powodzenia. Są one szczególnie bolesne, gdy obserwują je przedstawiciele drugiej płci, a równocześnie normalne, biorąc pod uwagę inny przebieg rozwoju reprezentantów każdej z płci.

Słowa kluczowe: edukacja zróżnicowana; szkoły jednopłciowe; intymność; deintymizacja życia. 